\title{
Teachers' Perception of the Students' Foreign Language Learning and the Potential Role of ICT
}

\author{
María del Carmen Horno Chéliz, Universidad de Zaragoza, Zaragoza, Spain \\ Antonio Sarasa Cabezuelo, Universidad Complutense de Madrid, Madrid, Spain \\ (iD https://orcid.org/0000-0003-3698-7954
}

\begin{abstract}
This article focuses on the learning problems that arise in the teaching of second languages. Nowadays, the introduction of new technologies in this field has had a relevant effect by offering new possibilities that did not exist in the analogue era. However, many of the learning problems persist, and one of the causes identified is the change in learning styles. The use of new technologies has fostered an experimental learning style among students. This style is incompatible with traditional classes of theory and practice, in which an intellectual effort is required to understand the theory and then put into practice what has been learned. The present work starts from this reality and tries to provide possible improvements. For this, an analysis of the main problems encountered by the learners in the various linguistic acquisition components (lexicon, grammar and processes of comprehension and production, both oral and written) has been carried out. The method used was a questionnaire answered by 113 active language teachers. After the analysis of the answers received, a series of specific problems of the teaching-learning process was enumerated and different IT applications and ICT resources were searched that could solve or at least minimize them.
\end{abstract}

\section{KEYWORDS}

Communication Competences, ICT, Language Learning, Language Training, Teaching Second Languages

\section{INTRODUCTION}

One of the most important objectives in the teaching of second languages is to ensure that students acquire the skills to face various communicative activities of production and comprehension, both orally and in writing (De Europa, 2012), of the language under study. To achieve this goal, the teacher uses different resources that will provide the student with a set of comprehension strategies (identification of keys and inferences) and production (planning, compensation, control and correction) useful to acquire different communication skills in the language of study (Larsen-Freeman, 2014). In the case of listening comprehension, you need to listen to sound learning resources in the language of study such as public statements, media, songs, lectures, private conversations, etc. In the case of reading comprehension, you need to read different types of text documents written in the language 
of study such as instructions, newspapers, magazines, opinion articles, literary texts.... In the field of audiovisual understanding, it is necessary to access multimedia resources such as television programs, fiction films, reports, etc. And finally, for the activities of expression, interaction or mediation, it is necessary to be able to try different production models (public presentations, oral monologues, written essays, etc.) (McLaughlin, 1989).

The teacher will have to use and adapt these resources to the different learning styles presented by the students (Fernández, 2007). The mentioned learning resources can be analog or digital according to the nature of the technology used to create them. The analogical case is characterized by the fact that production requires a physical manufacturing process and access to resources is limited (Godwin-Jones, 2010) since to use it requires the resource to be physically available (for example, if a reading book is needed then it will have to be bought or borrowed from a library). Some examples of analogue resources are (Palma, 2016): books with grammatical contents and exercises to exercise vocabulary and grammatical constructions, reading books in the study language adapted to different levels of skill, bilingual paper dictionaries, tapes or discs with sound recordings used for listening comprehension, videos to work on audiovisual comprehension (verbal and non-verbal language), vocabulary cards, etc. Digital resources are an equivalent electronic reproduction (Golonka, 2014) of resources and analog learning strategies (for example, physical dictionaries have given rise to online dictionaries). Its introduction in teaching has been varied (Chun, 2016). In some cases, digital resources have replaced analogue equivalents (Blake, 2009), and in other cases analogue resources have been maintained and used as a complementary tool (Blake, 2013). The impact of digitalization is materialized, among other aspects, in the possibility of accessing features that were not possible with physical means (Nomass, 2013) such as the availability of simple, rapid and universal access to resources or access to digital repositories with learning resources in different formats prepared specifically for the teaching of second languages (Levy, 2009).

The nature of the resources influences how they can be used by students and teachers (Richards, 2015). In this sense, analog resources are generally designed to be used with the presence of a teacher who will guide and evaluate learning (Cook, 2013). Classes are based on the presentation of theoretical concepts that are illustrated later with the realization of exercises that put into practice what is seen in the theory. On the other hand, the evaluation with analogical resources is characterized by being manual (Crusan, 2016) with a direct intervention of the teacher (James, 2013). In this sense, the evaluation is generally based (Walker, 2016) on the realization of a written examination with questions of various types (true or false, questions to complete, group, writing, etc.), a test of oral expression through a conversation with the teacher, a listening comprehension test consisting of asking questions about the content of an audio that has been reproduced and a written comprehension test by asking questions about a text read by the students. In the digital world, some of the characteristics of use of the analog world are maintained, however new ones are introduced. Thus, the possibility of adapting the contents dynamically to the learning style of a student arises (Van Essen, 2014), it has the availability of technological tools to evaluate in a semi-automatic way linguistic skills such as pronunciation and oral expression (Jones, 2016) or the skill in writing and using the grammar and vocabulary of a language, or it is possible to receive almost immediate feedback about the activities carried out by a student (Chiu, 2013).

Despite the diversity and possibilities offered by learning resources (especially digital resources), second language students continue to have learning problems in the various linguistic competences. For example, the European Study of Linguistic Competence (ESLC), proposed by the European Commission in 2005 and supported by the European Parliament in 2006, shows widespread problems of oral and written comprehension in students of second languages such as English, French or German (EECL, 2012: 91). Other studies (Sparks et al., 1993) agree on the difficulties that students present in aspects such as the acquisition of vocabulary, good use of grammar, or non-verbal comprehension (Erhman, 1996). 
One of the main causes of the learning problems discussed is the change in the learning styles of the students (Kolb, 2014). The use of mobile devices and new technologies in general, has led to a change in the learning style of students (Chen, 2015). In this sense, there are numerous studies that have shown a correlation between their use and the preferred way to access information and acquire new knowledge (Surjono, 2015). Digital technology promotes access to information in an immediate way through intuitive mechanisms (Arellano et al., 2016), and acquiring knowledge through experimentation (the most common learning method is to test and see the effects, and then, starting of the experience developed, draw conclusions and generalize what has been learned). This phenomenon is seen in a clearer way in the digital natives than in people born in the analogue era and who have subsequently incorporated the use of digital media (Chan, 2014). The experimental learning style is incompatible (Rogowsky, 2015) with traditional forms of teaching that are geared towards a more theoretical learning style (Kanadli, 2016). In the theoretical learning style, the conceptual exposition of knowledge prevails, so that once assimilated they can be put into practice, and therefore the acquisition of knowledge is not so immediate because it requires the previous intellectual effort to understand the theory (Felder et al., 1995). The theoretical learning style has been widely used in the field of second language teaching (Oxford, 2003). Thus, a standard form of teaching consists of intercalating theoretical contents and illustrating them with practical exercises that affect the grammar or vocabulary seen in the theory. This form of teaching conflicts with the experimental learning style (Skehan, 1991), since the student expects to acquire knowledge more immediately and by generalization of particular situations or cases (Johnson, 2017).

To solve this situation the teacher can use digital resources that are the ones that best adapt by their nature to the new learning styles of the students. However, the teacher finds a huge variety of tools and computer applications available that make it difficult to choose and how to use them in a coordinated and coherent way (Salaberry, 2001).

This article presents a work that aims to help teachers of second language teaching to choose the best tools and digital resources to solve the learning problems found in students. For this, following studies such as that of García Laborda et al. (2012), we designed a questionnaire in which information about second language learning needs was collected. However, unlike that study, the questionnaire here was not addressed to the students themselves. On the contrary, in this work, it has been considered necessary to start from the opinion of the experts most linked to this process, that is, the teachers of second languages themselves. The second section details the way in which this information has been gathered: the elaboration of a survey in which one inquired about the needs detected when teaching and learning each one of the basic competences. The third section shows the results of the survey and the fourth proposes a series of ICT tools that help to solve the problems detected by teachers. The article will end with a discussion of this research.

\section{METHODS}

The experimental work is based on the analysis of the answers given by a sample of teachers of second languages to a questionnaire. Teachers are the best source of information on the difficulties they have to teach and on the problems they observe in students to learn. In this sense, the objective of this questionnaire was to know the opinion of teachers of second languages about the problems that their students have in the process of acquiring a foreign language.

In order to create the questionnaire we used the Google Drive tool. The questionnaire and the questions are written in Spanish since the sample of participating teachers were Spanish speakers. As we can see in the following link: https://docs.google.com/forms/d/18nC5jnoz2E0v8sQXbtIHTr YaPUqDhrTv8gXa1jlIi9U/edit, the questions asked are divided into two groups:

- Eight questions referred to the teacher's profile: It consists of questions that seek to describe the teacher, and are about sex, age, maximum academic title of teacher, experience in teaching 
second languages, languages he has taught, people he has taught (children, adolescents, etc.), the kind of tics tools used in the classes, and the general opinion about the progress and difficulties that the students find in the learning. There are unique answer questions (for example the questions about age, sex) and other multiple answer questions (languages you have taught, people you have taught, etc.). Some questions were partially closed (with the inclusion of an "other" in which they were allowed to write more information);

- Eight questions about learning difficulties: It consists of questions that try to describe the learning problems that teachers have observed in their students. In this sense, seven basic aspects that intervene in the learning process of a foreign language were considered: (1) the acquisition of the lexicon; (2) oral expression; (3) written expression; (4) oral comprehension; (5) written comprehension; (6) the interaction and (7) the evaluation. So, this part of test constists of 7 multiple questions with partially closed answers (included among the answer is an "other" that allows them to write other answers not contemplated) and an open question in which they can add more information about learning difficulties.

We begin with the study of the lexicon. Following Agustin Llach (2013), there are two processes of vocabulary acquisition in a second language: incidental and intentional learning. For incidental learning, the student must be exposed to a large amount of vocabulary, so one of the causes of the failure of their learning may be the lack of input (option 1). For intentional learning, on the other hand, the student must be motivated and s/he should not be bored, among other aspects. According to this, the questionnaire has considered the lack of these variables as causes of the failure of the process (options 2, 3). Lastly, some researchers consider that both processes (incidental and intentional) are essential and they must be combined in an appropriate way. Thornbury (2002) recommends, in any case, the practice spaced and distributed over a period of time to consolidate the vocabulary learned. In this sense, the lack of constancy (option 4) would be a problem for the acquisition of vocabulary.

Oral expression and interaction are surely one of the most important objectives for language students. Nevertheless, they are at the same time, the most complex activities. While one talks, knowledge of the lexicon, syntactic and discursive organization and pragmatic information, among many other elements (Baralo, 2000) intervene in real time. Such complexity makes the practice essential for its acquisition. Something similar happens in written expression. Even though students have more time to organize written speech, its complexity is not less. Therefore, practise is essential in both oral and written expression and interaction. In the questionnarie the most frequent causes for reducing this practice were listed: big ratios, lack of motivation, insecurity or lack of other context of interactions. The importance of oral and written comprehension are also undoubted (Cordoba et al., 2005; Cassany, 2005) The learner needs to have as much input as possible to improve these competences. The questionnaire listed the main causes to reduce listening and reading experiences.

Lastly, the researchs indicate that a good evaluation is essential for an adequate acquisition process, given that it is the way in which students receive feedback on their behavior and how they can improve it. We are thinking of a formative evaluation, which takes place throughout the entire process (García Santa-Cecilia, 1995). For this, it is essential that it be immediate, constant and objective. In the questionnaire we mentioned the main problems associated with it.

The questionnaire was filled online in september of 2016. The sample of participating teachers was 113 teachers ( 87 women and 26 men) and the collected data can be consulted at the following address: https://drive.google.com/open?id=1fq-wFlHSUr7ceXkB91o4ODVfBm6ZA6rV

In the sample, there is $55.8 \%$ (63) fall within the 30 to 45 age range; 36 (31.9\%) within the 46 to 65 age range; $13(11.5 \%)$ are younger than 30 , and only 1 person $(0.9 \%)$ is over 66 . As for their training, 53 of them (46.9\%) hold undergraduate degrees in philology or linguistics - regardless of whether they have additional training in language teaching; $28 / 24.76 \%$ ) hold a master's degree in language teaching (applied linguistics); $18 / 16.1 \%$ ) hold degrees in teaching, and only 10 (8.9\%) 
hold Ph.D. degrees in applied linguistics. The rest (2.65\%) ticked the "Other" box: 1 holds a degree in Education, 1 has a post-graduate diploma, and 1 has a degree in translation and interpretation.

Regarding their work as second-language teachers, most of them $(47: 41.6 \%)$ have been working for 6 to 15 years; 32 (28.3\%) for 1 to 5 years; and 31 (27.4\%) for more than 15 years. Only 3 of them $(2.7 \%)$ have been working as second-language teachers for less than one year. The languages taught are Spanish (taught by $75.2 \%$ of respondents), English (46\%), French (20.4\%), German and Catalan (5.3\% each); 4 taught Latin and 4 Italian (3.9\% each), 3 taught Greek (2.6\%), 2 Basque and 2 Arabic (1.8\% each), 1 Japanese and 1 Chinese (0.9\% each). Most of them (86, 76.1\%) specialise in the teaching of second languages to adults (companies, specific purposes, and higher education); Many of them $(72,63.7 \%)$ have taught teenagers; and 36 (31.9\%) have taught children. In addition, 23 of them have taught second languages to migrant adults and $1(0.9 \%)$ to autistic children.

The goal of this questionnaire was to find second-language teachers' views on the problems displayed by their students in the acquisition of a foreign language. To this end, we considered seven basic aspects in this process: (1) the acquisition of the lexicon; (2) oral expression; (3) written expression; (4) oral comprehension; (5) written comprehension; (6) the interaction and (7) the evaluation. The questions were partially closed (including "Other" in which they were allowed to freely write a brief text).

\section{RESULTS}

The answer to the first question (Which of the following problems would you connect to the acquisition of lexicon by your students?) given by most teachers (80\%) was the students' lack of constancy. The other answers - lack of motivation, lack of input, boredom - did not even reach 50\%: Even taking the margin for error (see Figure 1) into account, it seems clear that this is the teachers' preferred answer. As for the answers given under "Other", none of them was repeated and they all pertained to very specific circumstances, so they do not seem to have a general effect.

The second question (In the oral expression process, what is most interesting is for students to talk. Which of the following problems do you face in your everyday work in this regard?) received at least two significant answers: "Outside the class, they never speak the foreign language" (75\%), and "Students never speak in class out of embarrassment" (66\%). Less strong, but also significant (44\%) is the answer "Overcrowded classrooms. There is no time for everyone to talk" (see Figure 2). The answers to the open question did not coincide in this question either. In fact, the few teachers who used this option tended to repeat their previous answers.

Figure 1. Problems in lexicon acquisition

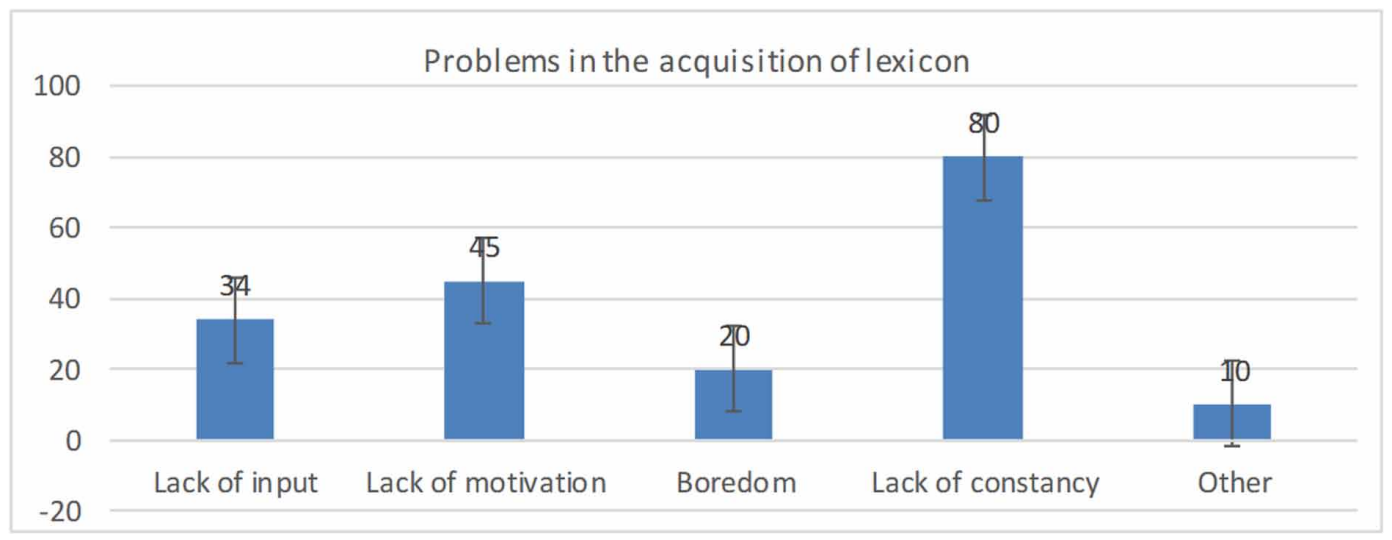




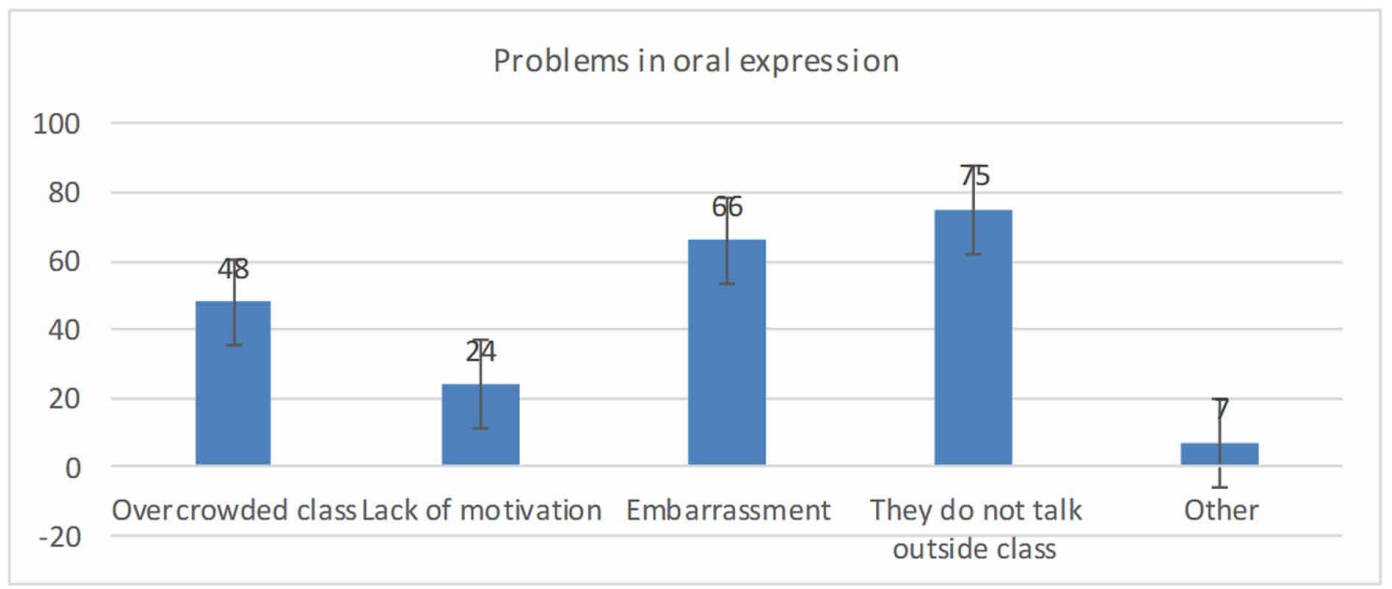

In the third question (Similarly, in the written expression process, what is most important is that students write. Which of the following problems reflect your experience?) again one answer is the preferred one without a doubt (see Figure 3): "Students do not write enough because they feel unable to on their own and there is no time in class" (58\%). As for the open questions, it is interesting to see that it is stated 6 times that problems with written expression in second languages arise from deficiencies in written expression in L1.

In the fourth question (In the aural comprehension process, students must receive sufficient aural input. Which of the following problems would you associate with your experience?) one answer prevails over the rest again: "They do not listen to more audios (or videos) outside class due to a lack of motivation" (72\%). As for open questions, several teachers agree on their students' lack of time (see Figure 4).

The fifth question (In the written comprehension process, students should read as many texts as possible. Which of the following problems would you associate with this process?) received a majority answer: "Students do not read too much because they lack motivation" (85\%). As for open answers, there are two generalised options: students' lack of time, and their lack of a reading habit

Figure 3. Problems in written expression

\section{Problems in written expression}

80

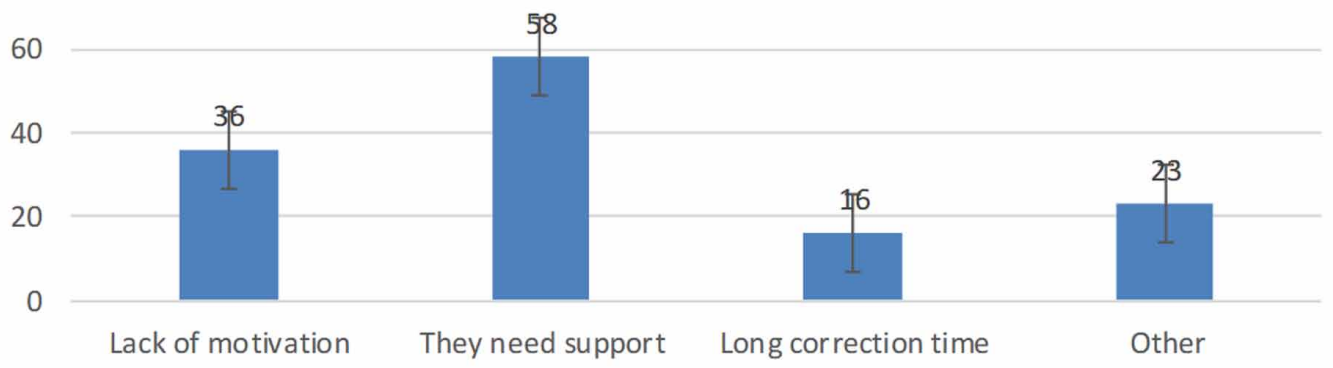




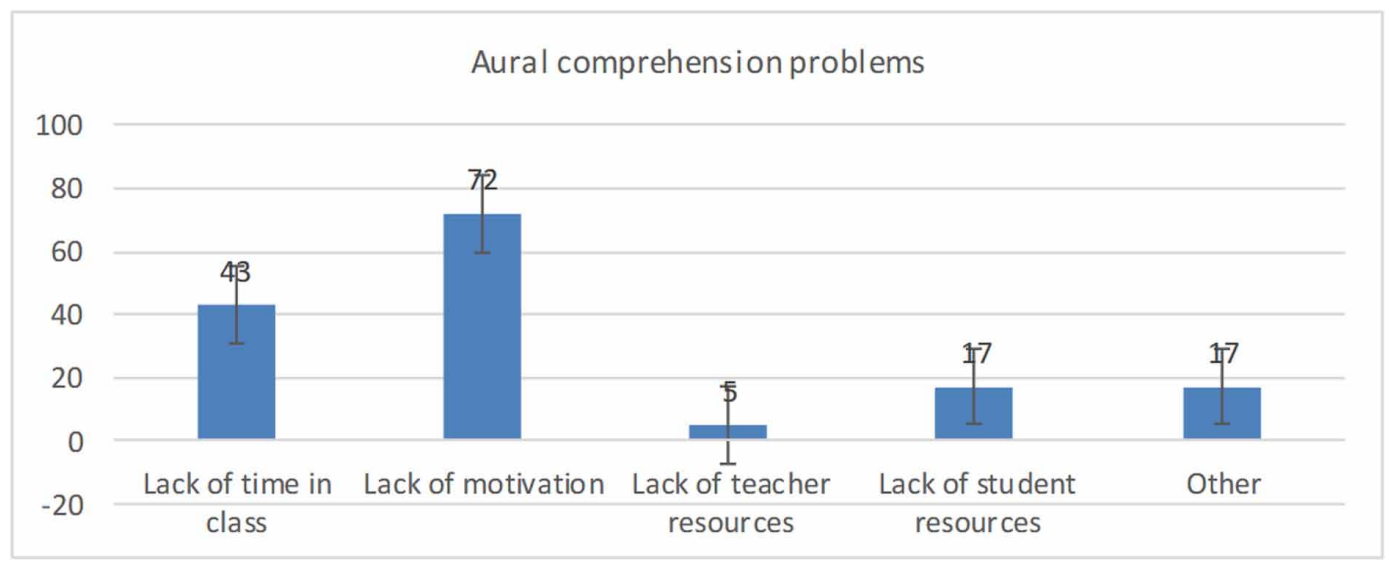

in their own native language. Several teachers also believe that there are no adequate texts for their students' level and age (see Figure 5).

There is a high degree of coincidence in the answers to the penultimate question (Which of the following problems would you associate with the acquisition of the interaction process?) (78\%): "Interaction outside class is not high because they do not have with whom to interact" (see Figure 6). As for open questions, the most frequent answer is student embarrassment.

Finally, the question "Which of the following problems would you associate with the evaluation of your students?" received two preferred answers: difficulties being objective (54\%) and the fact that evaluation cannot be immediate (44\%) (see Figure 7). There are no coincidences in the open questions.

\section{DISCUSSION AND CONCLUSION}

The goal of this paper, after examining the teachers' answers regarding their students, is to propose a number of ICT tools that help to overcome these deficiencies in the current second-language acquisition process. To this end, this section will include a subsection on each of the questions examined in the previous section.

Figure 5. Reading comprehension problems

\section{Reading comprehension problems}

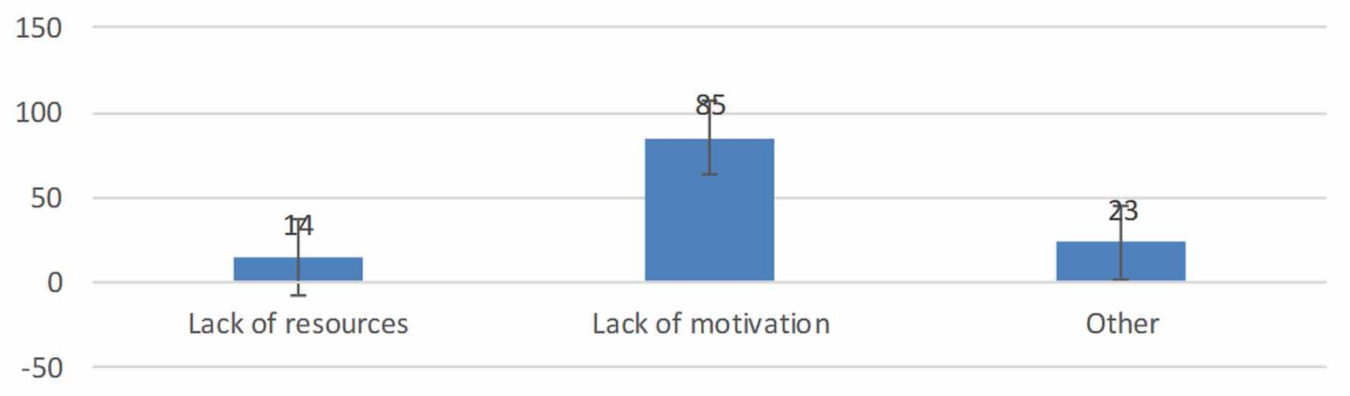




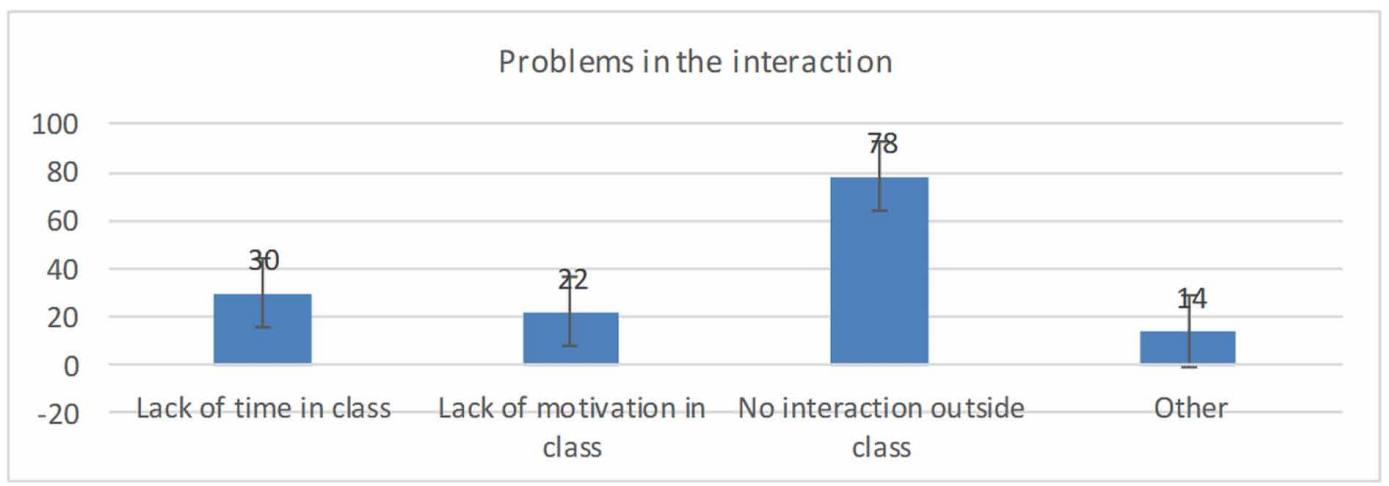

Figure 7. Problems in evaluation

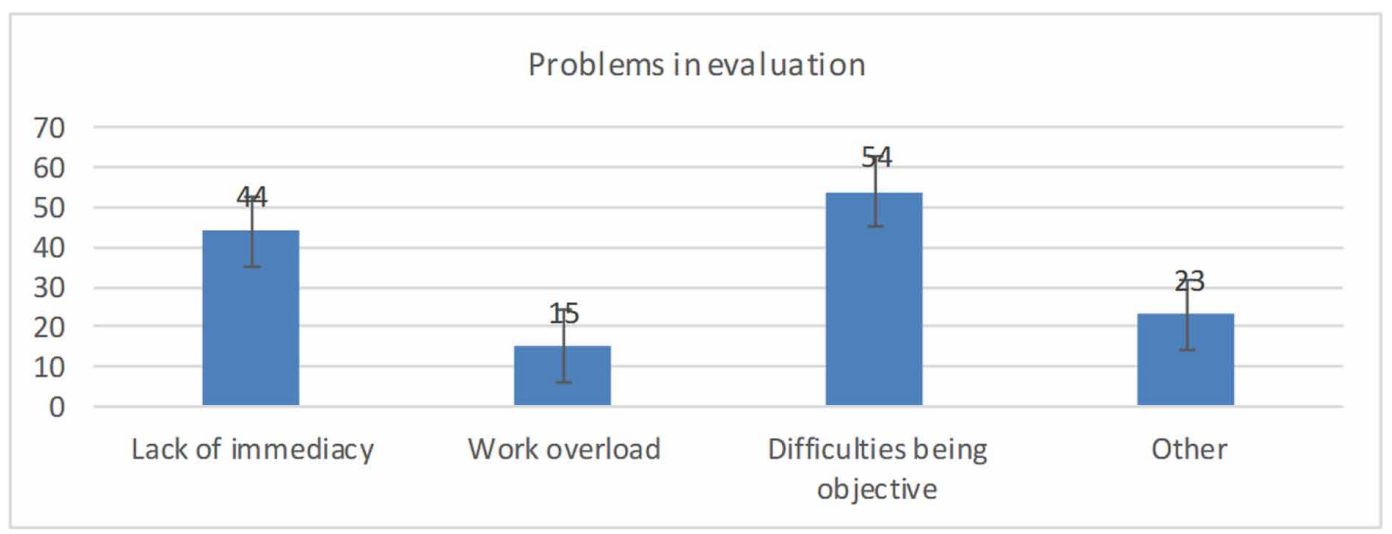

\subsection{Lexicon Acquisition}

Lexicon study is a crucial part of the acquisition of a foreign language. However, much grammar students know, if they do not have a sufficient lexicon, their possibilities of communication will be very limited. In this regard, ensuring that students acquire a rich and varied lexicon is a priority for any second-language teacher. According to the survey, the main problem identified by the teachers is students' lack of constancy. This result is consistent with the one found in the work of Laborda et alt (2012). There, students considered lack of motivation as one of their main problem.

To solve this problem and increase constancy, ICT tools aimed at lexicon acquisition have implemented strategies aimed at encouraging student motivation (Castillo et al., 2014) which have proven to be very effective (García, 2013; Munday, 2016; Ahmed et al., 2016; Osipov et al., 2015; Vesselinov et al., 2012). These strategies include:

- Virtual trainer: In general, this is a program that interacts with students and behaves like a real physical entity. The trainer's goal is to periodically encourage users to study and achieve goals previously established with the student (e.g. learning a certain number of words per week). Interaction can take place by means of notifications via email, in the mobile phone, or in the tool itself. The Duolingo tool (Huynh et al., 2016) materialises this strategy through the use of a trainer represented as an owl, which reminds students of the goals to be achieved (Martinez et al., 2018); 
- Reward system (Benítez, 2010): This strategy is based on rewarding or punishing the achievement of goals. Rewards can be of different types, such as access to restricted functionalities which are only available to a limited set of students, earning badges that show your achievements to other participants, and winning points that can serve to compare yourself to the other students or which can be used to buy services within the tool itself. In addition, punishments can take the form of the loss of points, badges, and other rewards previously earned. For example, in Duolinguo students receive visible badges to show the competences and level achieved (Kim et al., 2018), various achievements (passing a level, passing a unit, etc.) are rewarded with a virtual coin, and students with an outstanding level are given access to forums that are restricted to those who have reached that level. The failure to reach goals or the lack of constancy are also punished with the loss of the rewards earned;

- Group study: Another strategy with very positive effects on constancy in study is the possibility of studying with people you know. It can be implemented by offering the possibility of "following" certain students so that the follower can view certain information about the followed person, or else through the possibility of creating private student groups where you can interact with the other members using a communication tool, visualising other students' achievements, or receiving information about the activity which they have performing (Savvani, 2018). In Duolinguo, other students' progress can be followed. Thus, when a followed student passes a level or earns a badge, the students who follow him or her are informed;

- Mobile learning: Mobile devices have recently displaced PCs and laptops, among other reasons because they can be easily carried, apps can be used from any location, at any time, and they essentially offer similar services to those of a PC or laptop. This advantage has been considered by many ICT tools for lexicon acquisition, so that access to their services via mobile devices is offered to addition to access via PCs/laptops (Loewen, 2019). In some cases, two versions of the same tool have been created (one for PCs and another one for mobile devices), and in other cases the tool is a web app that has an online interface that adapts to PC and mobile device browsers;

- Learning reinforcement: Finally, another strategy used to encourage constancy in study is periodic reinforcement. To this end, tools monitor the student's activity on a regular basis, and if they detect signs of student abandonment or a level of activity lower than a set threshold, notifications are sent or some sort of punishment is applied (loss of badges, loss of points, blocking from forums, etc.) One of the goals is to maintain the knowledge acquired (Upadhyay, 2018). For example, in Duolinguo, this strategy is implemented by combining notifications and a loss of achievements. Thus, if a certain period of time has passed and a learning unit already passed has not been reviewed, the unit loses the gold colour that indicated mastery of the unit contents, and the connected achievements are deleted.

\subsection{Oral Interaction}

One of the basic goals of second-language students is oral communication in that language. In the questionnaire delivered, three questions are devoted to this competence $(2,4$, and 6 , see figures 2,4 , and 6). According to the results obtained, teachers believe that their students' main difficulty is the impossibility of interaction: in class there is not enough time for everyone to participate, and there are no contexts for interaction outside the class. Moreover, embarrassment problems must be overcome. All these results are consistent with Laborda et al. (2012). There, students added lack of confidence as one of the main causes of the embarrashment.

One ICT tool that has proven its effectiveness improving second-language students' oral competence is videocalls (Laaser, 1994). They can be used for this purpose in several ways. The first way is having videocalls with natives speakers of the language being study. In this regard, if offers many advantages for the learning of the language being study (Wang, 2004): 
- Conversations are real and spontaneous (and not artificial like those held in a face-to-face class). The memorised lexicon must be adequately used (Young et al., 2018), adapting to the way in which the conversation flows (change of topics, discussions arising over having different views on a topic, etc.);

- Oral interaction with a native speaker will contribute richness to the lexicon and the syntactic structures employed (Nobre, 2018);

- Students are forced to apply all the resources learnt in class to understand and make themselves understood, which facilitates making knowledge automatic. In addition, the real nature and the difficulty of having a conversation with a native speaker is further motivation for the student (Tecedor, 2019);

- It makes it possible for students to review and understand certain language elements that have not been adequately understood or assimilated in class and which are correctly reproduced in the conversation with the native speaker (Vurdien, 2019);

- It encourages cultural exchange on aspects such as customs or the types of oral interaction that take place in the language being studied (Dai, 2019);

- As for competences, the acquisition of digital, intercultural, and pragmatic-discursive competences is encouraged (Llano et al., 2011).

Another way to make use of a videocall is to use it as a learning resource in class (Hampel et al., 2004). To this end, the teacher proposes conversation topics to the students, who must elaborate on them by videocall. To guarantee the effectiveness of these activities it is recommended (Lamy, 2004) that topics focus on real conversation situations (e.g. topics connected to cultural customs) to encourage group participation. Likewise, the performance of collaborative written production tasks could be interspersed in the conversations (focusing on contents, not on linguistic-grammatical aspects) among participants to encourage oral communication.

In addition, it is crucial that students listen to the second language, to improve their oral comprehension as well as to improve their production. In this case, when asked why students do not access more audios or videos in the second language, the teachers agreed on a lack of student motivation. In addition, several teachers added in the open question that their students had a real problem of lack of time, as they had to combine their learning with other studies, work, and family duties.

To cover these needs, mobile learning (Robles, 2011) provides numerous advantages (Sariola et al., 2001), such as general motivation regarding the use of mobile devices, the possibility of accessing learning resources at any time and in any location, and portability between devices. There are several strategies to implement $\mathrm{m}$-learning in the teaching of second languages, including podcasts (Stanley, 2005) and video podcasts (Cabero-Almenara, 2007). Podcasts have been extensively used given their effectiveness in several aspects, such as improving pronunciation (Abdous et al., 2009), strengthening aural skills (Lee et al., 2008), and acquiring lexicon (Chacón et al., 2011). Regarding video podcasts, their main advantage is students' motivation and emotional attitude (Kay, 2012; Mattera et al., 2013) towards the use of video as a tool and a learning instrument (it is perceived as entertaining, motivating, etc.) Use of video has also been effective in second-language learning in the following regards:

- It facilitates the development of pragmatic skills (Rifkin, 2000), as video gives access to real situations in which linguistic, social, and cultural information connected to the language being studied is obtained (Rogers et al., 1988);

- It improves students' communication skills (Weyers, 1999). In particular aural comprehension (Álvarez, 2016);

- It makes it possible to work on non-verbal elements (attitudes, gestures, etc.) as well as linguistic aspects in the relevant contexts (Arellano et al., 2000);

- It makes it possible to automate actions and approaches, and synthesise ideas and concepts (Martínez, 2009). 


\subsection{Written Interaction}

Even though written expression has been the basis of language learning until quite recently, secondlanguage students cannot be said not to have problems when facing the empty page (or screen), or that their reading comprehension is impeccable. The questionnaire includes two questions to evaluate the needs identified by teachers in this respect (see figures 3 and 5). The answers to the first one indicate that students need more support in their written production process. ICT tools that provide assistance are required. In this regard, there are several options: forum, blog, or wiki (Miyazoe et al., 2010). However, several studies (Del Moral, 2007) show that students display a greater improvement in their written expression when wikis have been used to perform this kind of activity. The reasons that make wikis interesting are:

- Monitoring: It allows teachers to instantly monitor (Bruns et al., 2005) students' progress, observing their comments and individual activity, as well as making comments, suggestions, or individual corrections regarding the activities performed (Ben-Zvi, 2007). Moreover, students can compare their progress or examine their mistakes, comparing the different versions of a specific activity;

- Motivation: The fact that what is published on a wiki can be accessed by the other users encourages students to make the best possible contributions (Bruns et al., 2005);

- Collaborative learning: A wiki facilitates performing a written expression activity collaboratively, so that the students who participate can learn from others' mistakes and success (Xiao et al., 2008), and correct each other.

Some specific ways to use wikis to improve written expression are (West et al., 2009): activities involving the analysis and improvement of a text that includes mistakes or can be improved (Araujo, 2014), activities involving direct expression regarding a specific topic (Santamaria et al., 2006), activities regarding the discussion of a text or topic to work on students' rhetorical, discursive, and argumentative skills (Bruns et al., 2005), and activities regarding the creation of a glossary (Shih et al., 2008).

As for why students do not read enough, the teachers who took the survey felt that they lack motivation. Above all, because they are not used to reading in their native language either, and because they do not have much time. In addition, there is a lack of specific resources for the students' age and level. Motivating, specific resources that are easy to access are required. In this regard, e-books (Vassiliou et al., 2008) are an ICT tool that has proven to be effective to cover this need (Xu, 2010; Plass et al., 1998; Plass et al., 2005) for the following reasons:

- High availability: In recent years, a large number of libraries, universities, companies like Google, and initiatives like the Gutenberg Project and Open Library (De la Nuez Placeres et al., 2014) have digitalised their non-copyrighted editorial funds, making them freely available for any user to download and read them. Moreover, a large number of publishing houses and magazines have started to digitalise their funds;

- Motivation (Ramírez et al., 2013): The technical possibilities of e-readers make it possible to present contents in a more appealing way than physical books, take up less space than physical books, can store thousands of books in a single device, can be easily shared and distributed, and offer a wide range of tools aimed at readers (Armañanzas, 2010), such as: electronic annotation, searches within the book contents that allow readers to find the relevant page, digital bookmarks, use of embedded dictionaries, and the possibility of adding supplementary contents (links, multimedia resources, and other elements for interaction that offer additional information about the contents);

- Improvement of reading habits (Mayer, 2003): There are several strategies for use in language learning: use of e-books with audio (Mediatore, 2003), creation of a collection of suggested books 
(Keengwe et al., 2014), use of e-books with educational activities (Aedo et al., 2000), and use of annotated e-books (Ariew et al., 2004).

\subsection{Evaluation}

Another aspect that was taken into account in this survey was the process for student evaluation. In this regard, the survey shows that teachers being unable to offer immediate feedback on their evaluation, as well as having to way to provide objective evaluation, problematic. This is really important, because only if the evaluation is inmediate and objective it could be an aid to the learning process. Again, the study of Laborda et alt (2012) saw students have a similar point of view, and they consider evaluation is not useful to improve language acquisition.

Regarding the first problem, ICT tools are an ideal mechanisms, as they precisely make it possible to automate correcting students' exercises. This feature is general for any ICT tool, as they are precisely designed to encourage access to information in a simple and almost immediate manner (Matera et al., 2006). It is true that the degree of automation in correction depends on the type of evaluation exercise (e.g. open-answer questions are hard to automate, but multiple choice tests are corrected immediately and automatically). In this regard, most of the ICT tools used in secondlanguage teaching offer teachers features to create student evaluations in which they can generate exam questions that allow for automated correction, such as multiple-choice tests, word ordering, filling gaps with the right word, connecting words, etc. (Flores, 2012). In this way, students can be immediately offered feedback.

Regarding the objectivity of the evaluation of more open-ended exercises one of the most effective mechanisms is the use of rubrics (Gottlieb, 2006). Firstly, they guarantee the uniform correction and interpretation of evaluation by various correctors, as well as by the same corrector different times, thanks to the existence of explicit criteria (Mansilla et al., 2009), and make it possible to describe the different potential levels of achievement by a student (Griffin, 2009). In foreign language teaching, a specific rubric model is that given in the European Common Reference Framework descriptor scale, with six performance levels, from A1 to C2, for different linguistic usage and comprehension and production skills.

The introduction of the new technologies has made it possible to develop what are known as e-rubrics, which make it possible to digitally design a rubric and apply it to evaluation semiautomatically, in order to monitor the student's progress. Thus, for example, the use of e-rubrics has become widespread among international foreign language evaluation agencies to evaluate the 4 linguistic levels (Al-Jarf, 2011): aural comprehension, oral expression, and written comprehension and expression. Cambridge International Examinations and Pearson Language Assessments are examples of this. Holistic rubrics (on a one-dimensional scale) have also tended to be used recently to evaluate written production. In this regard, there are studies that prove that e-rubrics improve the reliability of holistic correction of texts (Attali et al., 2012) and supplement the assessments made by human evaluators (Enright et al., 2010). Likewise, the systems that implement this kind of e-rubric provide students with feedback on the work performed on the basis of a holistic rubric on pre-established criteria.

\section{ACKNOWLEDGMENT}

This work has been carried out within the consolidated groups of the Psylex DGA and ILSA group UCM. Likewise, it has benefited from four research projects funded by the Ministry of Economy and Competitiveness of Spain: the project FF12017-82460-P, "Concept, Structure, Sound (CONESSO)", the project FFI2015-63497-P, " the Semantic / Pragmatic interface and the resolution of interpretive imbalances "(SPIRIM), the project RedR+Human (TIN2014-52010-R) and the project CetrO+Spec (TIN2017-88092-R). 


\section{REFERENCES}

Abdous, M. H., Camarena, M. M., \& Facer, B. R. (2009). MALL technology: Use of academic podcasting in the foreign language classroom. ReCALL, 21(1), 76-95. doi:10.1017/S0958344009000020

Aedo, I., \& Díaz, P. (2000). Diseño de libros electrónicos educativos. In Proceedings of the Actas de las I Jornadas Interacción' 2000. Academic Press.

Agustin Llach, M.P. (2013). Dinámica del aprendizaje incidental de léxico en lengua extranjera. Revista Nebrija de Lingüística Aplicada a la Enseñanza de Lenguas, (14), 34-39.

Ahmed, H. B. E. (2016). Duolingo as a Bilingual Learning App: A Case Study. Arab World English Journal, 7(2), 255-267. doi:10.24093/awej/vol7no2.17

Al-Jarf, R. (2011). Creating and sharing writing iRubrics. Asian EFL Journal. Professional Teaching Articles, $51,41-62$.

Álvarez Álvarez, A. (2016). El uso del vídeo como factor de aprendizaje en una clase de francés lengua extranjera. Didáctica, innovación y multimedia, (33), 1-10.

Araujo, J.C. (2014). El uso de blogs, wikis y redes sociales en la enseñanza de lenguas. EDUTEC. Revista Electrónica de Tecnología Educativa, 49.

Arellano, M. D. C., \& Fernández, D. M. (2009). Desarrollo de la comprensión oral en inglés como LE al término de la Educación Secundaria Obligatoria española. Porta Linguarum: revista internacional de didáctica de las lenguas extranjeras, (11), 129-145.

Arellano, P. R., \& Geijo, P. M. (2016). Una mirada a los estilos de enseñanza en función de los estilos de aprendizaje. Journal of Learning Styles, 9(18).

Ariew, R., \& Ercetin, G. (2004). Exploring the potential of hypermedia annotations for second language reading. Computer Assisted Language Learning, 17(2), 237-259. doi:10.1080/0958822042000334253

Armañanzas, E. (2010). El libro electrónico, una gran herramienta para la cultura y la educación. In Actas del Congreso Euro-Iberoamericano. Alfabetización mediática y culturas digitales. Universidad de Sevilla.

Attali, Y., Lewis, W., \& Steier, M. (2012). Scoring with the computer: Alternative procedures for improving the reliability of holistic essay scoring. Language Testing, 30(1), 125-141. doi:10.1177/0265532212452396

Baralo, M. (2000). El desarrollo de la expresión oral en el aula de ELE. Madrid, en Carabela, Sociedad Española de Librería, (47), 5-36.

Ben-Zvi, D. (2007). Using wiki to promote collaborative learning in statistics education. Technology Innovations in Statistics Education, 1(1).

Benítez, G. S. (2010). Las estrategias de aprendizaje a través del componente lúdico. MarcoELE: Revista de Didáctica Español Lengua Extranjera, (11), 20.

Blake, R. J. (2009). The use of technology for second language distance learning. Modern Language Journal, 93(s1), 822-835. doi:10.1111/j.1540-4781.2009.00975.x

Blake, R. J. (2013). Brave new digital classroom: Technology and foreign language learning. Georgetown University Press.

Bruns, A., \& Humphreys, S. (2005). Wikis in teaching and assessment: The M/Cyclopedia project. In Proceedings of the 2005 international symposium on Wikis (pp. 25-32). ACM. doi:10.1145/1104973.1104976

Cabero-Almenara, J. (2007). El vídeo en la enseñanza y formación. In Nuevas tecnologías aplicadas a la educación (pp. 129-150). Síntesis.

Cassany, D. (2005). Expresión escrita en L2/ELE. Madrid: Arco Libros.

Castillo, A. A., Lozano, C. A. F., \& Pineda, W. F. R. (2014). Aprende jugando: El uso de técnicas de gamificación en entornos de aprendizaje. IM-Pertinente, 2(1), 125-143. 
Chacón, C. T., \& Pérez, M. A. (2011). El podcast como innovación en la enseñanza del inglés como lengua extranjera. Píxel-Bit. Revista de Medios y Educación, 39, 41-54.

Chan, S., \& Denner, P. R. (2014). Effects of Learning Styles on Learners' Preferences between PowerPoint and White/Chalkboard Lectures. International Journal of Academic Research in Education and Review, 2(9), 220-230.

Chen, Y. C. (2015). Linking learning styles and learning on mobile Facebook. The International Review of Research in Open and Distributed Learning, 16(2). doi:10.19173/irrodl.v16i2.2038

Chiu, Y. H. (2013). Computer-assisted second language vocabulary instruction: A meta-analysis. British Journal of Educational Technology, 44(2), E52-E56. doi:10.1111/j.1467-8535.2012.01342.x

Chun, D., Kern, R., \& Smith, B. (2016). Technology in language use, language teaching, and language learning. Modern Language Journal, 100(S1), 64-80. doi:10.1111/modl.12302

Cîrnu, C. E., Zamfiroiu, A., \& Anghel, M. (2015). Using graphic libraries for foreign languages educational games. eLearning \& Software for Education, (2).

Cook, V. (2013). Second language learning and language teaching. Routledge.

Cordoba Cubillo, P., Coto Keith, R., \& Ramírez Salas, M. (2005). La comprensión auditiva: Definición, importancia, características, procesos, materiales y actividades. Actualidades Investigativas en Educación, $5(1), 1-17$.

Crusan, D., Plakans, L., \& Gebril, A. (2016). Writing assessment literacy: Surveying second language teachers' knowledge, beliefs, and practices. Assessing Writing, 28, 43-56. doi:10.1016/j.asw.2016.03.001

Dai, Y. (2019). Situating videoconferencing in a connected class toward intercultural knowledge development: A comparative reflection approach. The Internet and Higher Education, 41, 1-10. doi:10.1016/j.iheduc.2018.11.001

De Europa, C. (2002). Marco común europeo de referencia para las lenguas. Strasburgo: Consejo de Europa. Ministerio de Educación, Cultura y Deporte/Instituto Cervantes.

De la Nuez Placeres, G., \& Suárez, J. A. S. (2014). Innovar para educar: Uso de los dispositivos móviles en la enseñanza y aprendizaje del inglés. Historia y Comunicación Social., 19(1), 771-779.

Del Moral, M. (2007). Una herramienta emergente de la Web 2.0: la wiki. Reflexión sobre sus usos educativos. Unión: revista iberoamericana de educación matemática, (9), 73-82.

Ehrman, M. E. (1996). Understanding second language learning difficulties. Sage (Atlanta, Ga.).

Enright, M. K., \& Quinlan, T. (2010). Complementing human judgment of essays written by English language learners with e-rater® scoring. Language Testing, 27(3), 317-334. doi:10.1177/0265532210363144

Estudio Europeo de Competencia Lingüística (EECL). (2012). Ministerio de Educación. Madrid: Cultura y Deporte.

Felder, R. M., \& Henriques, E. R. (1995). Learning and teaching styles in foreign and second language education. Foreign Language Annals, 28(1), 21-31. doi:10.1111/j.1944-9720.1995.tb00767.x

Fernández, F. M. (2007). Adquisición de segundas lenguas y Sociolingüística. Review of Education, 343, 55-70.

Flores Alarcia, Ó. (2012). TIC y docencia universitaria:‘ cambian las metodologías docentes según el grado de presencialidad de las asignaturas? El caso de la Universidad de Lleida. Píxel-Bit. Revista de Medios y Educación, (41).

García, I. (2013). Learning a language for free while translating the web. does duolingo work? International Journal of English Linguistics, 3(1), 19. doi:10.5539/ijel.v3n1p19

García Santa-Cecilia, A. (1995). El curriculo del español como lengua extranjera. Fundamentación metodológica, planificación y aplicación. Madrid: Edelsa.

Godwin-Jones, R. (2010). Emerging technologies from memory palaces to spacing algorithms: Approaches to second language vocabulary learning. Language Learning \& Technology, 14(2), 4-11. 
Golonka, E. M., Bowles, A. R., Frank, V. M., Richardson, D. L., \& Freynik, S. (2014). Technologies for foreign language learning: A review of technology types and their effectiveness. Computer Assisted Language Learning, 27(1), 70-105. doi:10.1080/09588221.2012.700315

Gottlieb, M. (2006). Assessing English language learners: Bridges from language proficiency to academic achievement. Corwin Press.

Griffin, M. (2009). What is a rubric? Assessment Update, 21(6), 4-13.

Hampel, R., \& Hauck, M. (2004). Towards an effective use of audio conferencing in distance language courses. Language Learning \& Technology, 8(1), 66-82.

Huynh, D., Zuo, L., \& Iida, H. (2016, December). Analyzing Gamification of "Duolingo" with Focus on Its Course Structure. In Proceedings of the International Conference on Games and Learning Alliance (pp. 268277). Cham: Springer. doi:10.1007/978-3-319-50182-6_24

James, C. (2013). Errors in language learning and use: Exploring error analysis. Routledge. doi:10.4324/9781315842912

Johnson, K. (2017). An introduction to foreign language learning and teaching. Routledge.

Jones, L. C. (2016). Using technology in language teaching and listening comprehension: Revisiting what teachers should know and do. IALLT Journal of Language Learning Technologies, 34(2).

Kanadli, S. (2016). A meta-analysis on the effect of instructional designs based on the learning styles models on academic achievement, attitude and retention. Educational Sciences: Theory and Practice, 16(6), 2057-2086. doi:10.12738/estp.2016.6.0084

Kay, R. (2012). Exploring the use of vídeo podcasts in education: A comprehensive review of the literature. Computers in Human Behavior, 28(3), 820-831. doi:10.1016/j.chb.2012.01.011

Keengwe, J., \& Bhargava, M. (2014). Mobile learning and integration of mobile technologies in education. Education and Information Technologies, 19(4), 737-746. doi:10.1007/s10639-013-9250-3

Kim, S., Song, K., Lockee, B., \& Burton, J. (2018). Gamification cases in liberal arts and social science education. In Gamification in learning and education (pp. 141-149). Cham: Springer. doi:10.1007/978-3-319-47283-6_12

Kolb, D. A. (2014). Experiential learning: Experience as the source of learning and development. FT press.

Laaser, W. (1994). Videoconferencias como recurso suplementario en sistemas de educación a distancia. Revista Iberoamericana de Educación Superior a Distancia, 6(3), 39-50.

Laborda, J. G., Bejarano, L. G., \& Simons, M. (2012). ¿Cuánto aprendí en la enseñanza secundaria? Las actitudes de los estudiantes universitarios de primer año respecto a la relación enseñanza-aprendizaje de su segunda lengua en la escuela secundaria en tres contextos internacionales. Educación XX1: revista de la faculdad de educación, 15(2), 159-184.

Lamy, M. N. (2004). Oral conversations online: Redefining oral competence in synchronous environments. ReCALL, 16(2), 520-538. doi:10.1017/S095834400400182X

Larsen-Freeman, D., \& Long, M. H. (2014). An introduction to second language acquisition research. Routledge. doi: $10.4324 / 9781315835891$

Lee, M. J., McLoughlin, C., \& Chan, A. (2008). Talk the talk: Learner-generated podcasts as catalysts for knowledge creation. British Journal of Educational Technology, 39(3), 501-521. doi:10.1111/j.14678535.2007.00746.x

Levy, M. (2009). Technologies in use for second language learning. Modern Language Journal, 93(s1), 769-782. doi:10.1111/j.1540-4781.2009.00972.x

Llano, J., Ainciburu, M. C., \& Lázaro, O. J. (2011). La Enseñanza de Español a través de Videoconferencias de Escritorio, Integración en las Diferentes Modalidades de Aprendizaje y Desarrollo de Competencias. Cuadernos Comillas, 2(18).

Loewen, S., Crowther, D., Isbell, D. R., Kim, K. M., Maloney, J., Miller, Z. F., \& Rawal, H. (2019). Mobileassisted language learning: A Duolingo case study. ReCALL, 1-19. doi:10.1017/S0958344019000065 
Mansilla, V. B., Duraisingh, E. D., Wolfe, C. R., \& Haynes, C. (2009). Targeted assessment rubric: An empirically grounded rubric for interdisciplinary writing. The Journal of Higher Education, 80(3), 334-353. doi:10.1080 /00221546.2009.11779016

Martínez, B. C., Pérez, C. A., Martínez, R. A. G., \& López, F. J. M. (2018). Integrando Duoling como herramienta tecnológica para la mejora del aprendizaje del idioma inglés. Pistas Educativas, 38(116).

Martínez, C. (2009). Aspectos didácticos sobre la utilización del vídeo en el aula de inglés. Cuadernos de Educación y desarrollo, 1(1).

Matera, M., Rizzo, F., \& Carughi, G. T. (2006). Web usability: Principles and evaluation methods. In Web engineering (pp. 143-180). Berlin: Springer. doi:10.1007/3-540-28218-1_5

Mattera, M., Baena, V., Ureña, R., \& de Fátima Moreno, M. (2014). Creativity in technology-enhanced experiential learning: Videocast implementation in higher education. International Journal of Technology Enhanced Learning , 6(1), 46-64. doi:10.1504/IJTEL.2014.060026

McLaughlin, B., \& Harrington, M. (1989). Second-language acquisition. Annual Review of Applied Linguistics, 10, 122-134. doi:10.1017/S0267190500001240

Mediatore, K. (2003). Reading with your ears: Readers' advisory and audio books. Reference and User Services Quarterly, 42(4), 318-323.

Miyazoe, T., \& Anderson, T. (2010). Learning outcomes and students' perceptions of online writing: Simultaneous implementation of a forum, blog, and wiki in an EFL blended learning setting. System. An International Journal of Educational Technology and Applied Linguistics, 38(2), 185-199.

Munday, P. (2016). The case for using DUOLINGO as part of the language classroom experience. RIED. Revista Iberoamericana de Educación a Distancia, 19(1).

Nobre, A. (2018). Multimedia technologies and online task-based foreign language teaching-learning. Tuning Journal for Higher Education, 5(2), 75-97. doi:10.18543/tjhe-5(2)-2018pp75-97

Nomass, B. B. (2013). The impact of using technology in teaching English as a second language. English Language and Literature Studies, 3(1), 111.

Osipov, I. V., Nikulchev, E., Volinsky, A. A., \& Prasikova, A. Y. (2015). Study of gamification effectiveness in online e-learning systems. International Journal of advanced computer science and applications, 6(2), 71-77.

Oxford, R. L. (2003). Language learning styles and strategies: Concepts and relationships. Iral, 41(4), $271-278$. doi:10.1515/iral.2003.012

Palma, C. M. (2016). Teaching Spanish as a foreign language: Tools and resources for the modern ELE teacher. International Journal of Research and Education, 1(1), 7.

Plass, J. L., Chun, D. M., Mayer, R. E., \& Leutner, D. (1998). Supporting visual and verbal learning preferences in a second-language multimedia learning environment. Journal of Educational Psychology, 90(1), 25-36. doi:10.1037/0022-0663.90.1.25

Plass, J. L., \& Jones, L. (2005). Multimedia learning in second language acquisition. The Cambridge handbook of multimedia learning, 467-488. doi:10.1017/CBO9780511816819.030

Ramírez, R. G., Gascó, J. G., Cortés, E. C., Lillo, F. G., Taverner, J. L., Lajara, B. M., \& Sáez, P. Z. (2013). E. books: ventajas e implementación. In XI Jornadas de Redes de Investigación en Docencia Universitaria: Retos de futuro en la enseñanza superior: Docencia e investigación para alcanzar la excelencia académica (pp. 411-426). Instituto de Ciencias de la Educación.

Richards, J. C. (2015). Error analysis: Perspectives on second language acquisition. Routledge. doi: $10.4324 / 9781315836003$

Rifkin, B. (2000). Video in the Proficiency-Based Advanced Conversation Class: An Example from the RussianLanguage Curriculum. Foreign Language Annals, 33(1), 63-70. doi:10.1111/j.1944-9720.2000.tb00891.x

Robles, H. S. (2011). Experiencia de podcasting en la enseñanza de una segunda lengua. Zona Próxima, (14). 
Rogers, C. V., \& Medley, F. W. Jr. (1988). Language with a purpose: Using authentic materials in the foreign language classroom. Foreign Language Annals, 21(5), 467-478. doi:10.1111/j.1944-9720.1988.tb01098.x

Rogowsky, B. A., Calhoun, B. M., \& Tallal, P. (2015). Matching learning style to instructional method: Effects on comprehension. Journal of Educational Psychology, 107(1), 64-78. doi:10.1037/a0037478

Salaberry, M. R. (2001). The use of technology for second language learning and teaching: A retrospective. Modern Language Journal, 85(1), 39-56. doi:10.1111/0026-7902.00096

Santamaria, F. G., \& Abraira, C. F. (2006). Wikis: posibilidades para el aprendizaje colaborativo em Educacion Superior. In Proceedings of the 8th International Symposium on Computers in Education (Vol. 2, pp. 371-378). Academic Press.

Sariola, J., Sampson, J., Vuorinen, R., \& Kynäslahti, H. (2001, May). Promoting mLearning by the UniWap project within higher education. In Proceedings of the International Conference on Technology and Education. Academic Press.

Savvani, S. (2018). State-of-the-Art Duolingo Features and Applications. In Proceedings of the International Conference on Interactive Collaborative Learning (pp. 139-148). Cham: Springer.

Shih, W. C., Tseng, S. S., \& Yang, C. T. (2008). Wiki-based rapid prototyping for teaching-material design in e-Learning grids. Computers \& Education, 51(3), 1037-1057. doi:10.1016/j.compedu.2007.10.007

Skehan, P. (1991). Individual differences in second language learning. Studies in Second Language Acquisition, 13(2), 275-298. doi:10.1017/S0272263100009979

Sparks, R., \& Ganschow, L. (1993). Searching for the cognitive locus of foreign language learning difficulties: Linking first and second language learning. Modern Language Journal, 77(3), 289-302. doi:10.1111/j.1540-4781.1993.tb01974.x

StanleyG. (2005). Podcasting for ELT.

Surjono, H. D. (2015). The effects of multimedia and learning style on student achievement in online electronics course. TOJET: The Turkish Online Journal of Educational Technology, 14(1).

Tecedor, M., \& Campos-Dintrans, G. (2019). Developing oral communication in Spanish lower-level courses: The case of voice recording and videoconferencing activities. ReCALL.

Thornbury, S. (2002). How to Teach Vocabulary. Harlow: Longman.

Upadhyay, U., De, A., \& Rodriguez, M. G. (2018). Deep reinforcement learning of marked temporal point processes. In Advances in Neural Information Processing Systems (pp. 3168-3178). Academic Press.

Van Essen, A., Jager, S., \& Nerbonne, J. (Eds.). (2014). Language teaching and language technology. Routledge. doi:10.4324/9781315078137

Vassiliou, M., \& Rowley, J. (2008). Progressing the definition of “e-book." Library Hi Tech, 26(3), 355-368. doi: $10.1108 / 07378830810903292$

Vesselinov, R., \& Grego, J. (2012). Duolingo effectiveness study. USA: City University of New York.

Vurdien, R. (2019). Videoconferencing: Developing Students' Communicative Competence. Journal of Foreign Language Education and Technology, 4(2).

Walker, L. (2016). The impact of using Memrise on student perceptions of learning Latin vocabulary and on long-term memory of words. Journal of Classics Teaching, 16(32), 14-20. doi:10.1017/S2058631015000148

Wang, Y. (2004). Supporting synchronous distance language learning with desktop videoconferencing. Language Learning \& Technology, 8(3), 90-121.

West, J. A., \& West, M. L. (2009). Using wikis for online collaboration: The power of the read-write web. John Wiley \& Sons.

Weyers, J. R. (1999). The effect of authentic video on communicative competence. Modern Language Journal, 83(3), 339-349. doi:10.1111/0026-7902.00026 
Xiao, Y., \& Lucking, R. (2008). The impact of two types of peer assessment on students' performance and satisfaction within a wiki environment. The Internet and Higher Education, 11(3-4), 186-193. doi:10.1016/j. iheduc.2008.06.005

Xu, J. (2010). Using multimedia vocabulary annotations in L2 reading and listening activities. CALICO Journal, 27(2), 311-327. doi:10.11139/cj.27.2.311-327

Young, E. H., \& West, R. E. (2018). Speaking practice outside the classroom: A literature review of asynchronous multimedia-based oral communication in language learning. The EuroCALL Review, 26(1), 59-78. doi:10.4995/ eurocall.2018.8599

María del Carmen Horno Chéliz has been a lecturer in General Linguistics at the University of Zaragoza since 1998, tenured since 2003. She holds a degree in Hispanic Philology from the University of Zaragoza (1996), a PhD from the same university (2001) and a degree in Psychology (clinical specialisation) by UNED (2014). Her main field of interest is the lexical-syntactic interface, both from a theoretical and experimental point of view (psycholinguistics, and from the point of view of Biolinguistics. She is the author of the book Lo que la Preposición Esconde (2001) and a co-editor of Gramática del Sentido: Léxico y Sintaxis en la encrucijada (2010, with José Francisco Val Álvaro), La Sabiduría de Mnemósine (2012, with José Luis Mendívil), Language from a Biological Point of View (2012, with Cedric Boeckx and José Luis Mendívil) and De la Unidad del Lenguaje a la Diversidad de las Lenguas (2013, with José Francisco Val et al.). Some of her research papers and conferences can be downloaded from her website https://unizar.academia.edu/CarmenHornoCh\%C3\%A9liz.

Antonio Sarasa Cabezuelo holds a BSc degree in Computer Sciences by UNED, an MSc degree in the Mathematics of Computer Science by the Complutense University of Madrid, an MSc degree in Computer Science by the Open University of Catalonia, and a PhD in Computer Science by the Complutense University of Madrid. He is currently an associate professor at the School of Computer Science in the Complutense University of Madrid, and a member of the ILSA research group (Implementation of Language-Driven Software and Applications, http://ilsa.fdi.ucm. es). His research focuses on e-Learning, markup languages and domain-specific languages. He was one of the developers of the Agrega project on digital repositories. He has presented over 50 research papers in national and international conferences. He is also a member of AENOR Subcommittee 36. 